\title{
ЗМІСТ ІНКЛЮЗИВНОЇ КОМПЕТЕНТНОСТІ ПСИХОЛОГА ЯК УЧАСНИКА КОМАНДИ СУПРОВОДУ ДІТЕЙ $З$ ОСОБЛИВИМИ ОСВІТНІМИ ПОТРЕБАМИ
}

\author{
Каріна Бірюкова \\ аспірантка кафедри психології особистості та соціальних практик \\ Інститут людини Київського університету імені Бориса Грінченка \\ 04212, Україна, м. Київ, вул. Маршала Тимошенка, 13 б \\ k.biriukova.asp@kubg.edu.ua, http://orcid.org/0000-0002-6158-5060
}

\begin{abstract}
Анотація
У статті йдеться про значущість ефективно організованого інклюзивного навчання як показника якісної освіти. Представлено дослідження науковців, яке виявило суттєву невідповідність української нормативно-правової бази стосовно інклюзивного навчання європейським цінностям та керівним засадам; сформульовано чинники складнощів впровадження інклюзивної освіти в Україні. Увага в статті концентрується на кадровому забезпеченні інклюзивної освіти, і передусім - на позиції психолога в інклюзивному освітньому просторі. Систематизовано нормативно-правові, методичні та дослідницькі матеріали, присвячені визначенню змісту та форм діяльності психолога в закладі освіти. Здійснено порівняльний аналіз щодо змісту та форм діяльності психолога та інших учасників команди супроводу в українському нормативно-правовому законодавстві. У статті наголошено на тому, що у стандарті «Практичний психолог закладу освіти» відсутня інклюзивна компетентність, а поняття «інклюзивне навчання» подано в переліку таких ситуативних втручань, як булінг, прояви насильства та шкідливі звички. Дослідження за доступними нам джерелами понятійного поля вислову «інклюзивна компетентність» виявило недостатню конкретику та відповідність цього поняття потребам часу. Висвітлено головну спрямованість статті, яка полягає в обгрунтуванні поняття «інклюзивна компетентність» практичного психолога як необхідної його здатності щодо професійної допомоги дітям 3 особливими освітніми потребами в закладі освіти. Розроблена нами структура інклюзивної компетентності охоплює особистісні, міжособистісні та діяльнісні компетенції; конкретизовано зміст цих компетенцій та зазначено найкращий формат їх становлення безпосереднє навчання із супроводом експертного коучингу. Орієнтир на інклюзивну компетентність при підготовці майбутніх психологів або в процесі підвищення кваліфікації вже досвідчених психологів дасть змогу сформувати їхні професійні уміння у відповідності до вимог часу; сприятиме поліпшенню фахової підтримки дітей 3 особливими освітніми потребами в закладах освіти.
\end{abstract}

Ключові слова: інклюзивна освіта, інклюзивна компетентність, особливі освітні потреби, професійний стандарт, міжособистісні та діяльнісні компетенції.

\section{Вступ}

В оприлюдненій минулого року Всесвітній доповіді з моніторингу освіти (Global Education Monitoring Report Summary, 2020) наголошено, що інклюзивна освіта є основою системи якісної освіти, що дає змогу кожному учню домогтися успіху та реалізовувати свій потенціал. Зазначено також, що ретельне планування і організація інклюзивної освіти можуть 
сприяти підвищенню успішності, соціально-емоційному та особистісному розвитку. У цій доповіді введено поняття «інклюзивність в освіті», що означає забезпечення такої ситуації, за якої кожен учень бачить, що його цінують й поважають, набуває почуття приналежності до дитячого колективу.

Незважаючи на те, що розвиток інклюзивної освіти в Україні розпочався більше десяти років тому, цей процес досі $\epsilon$ недостатньо продуманим і відповідним до міжнародних стандартів. Зумовлено це відсутністю Стратегії розвитку інклюзивної освіти, що позбавляє цей процес планування й організованості; наявні нормативно-правове, навчально-методичне, кадрове й фінансове забезпечення знаходяться на невідповідному рівні. Вагомим чинником невідповідності вітчизняної інклюзивної освіти є брак спеціально організованої роботи 3 розвитку професійної готовності студентів до практичної діяльності в інклюзивному освітньому середовищі відповідно до міжнародних вимог (Martynchuk, Skrypnyk, Maksymchuk, Babych \& Biriukova, 2021: 159-172). При цьому, з 2017 року, коли було прийнято новий Закон України «Про освіту», діти з ООП мають право здобувати освіту в усіх закладах освіти, що передбачає: організацію інклюзивних та спеціальних груп/класів, відповідне підлаштування освітнього простору, отримання кваліфікованої психолого-педагогічної допомоги тощо.

Одним 3 недостатньо розроблених питань в українській освітній політиці є кадрове забезпечення інклюзивної освіти, що стосується як підготовки фахівців, обізнаних з питань інклюзивної теорії й практики, так й підвищення кваліфікації наявних кадрів. У контексті нашої статті особливо хотілося б наголосити на вкрай недостатній увазі, яку приділяють формуванню так званої інклюзивної компетентності психологів та їхній здатності працювати в режимі командної взаємодії.

Так, в прийнятому Стандарті вищої освіти України за спеціальністю 053 «Психологія» (2019 р.), так само, як й в професійному стандарті «Практичний психолог закладу освіту» (2020 р.), перераховано різнопланові загальні компетентності, якими має володіти практичний психолог, при цьому інклюзивна компетентність відсутня, й навіть жодну з наявних компетентностей не конкретизовано змістом інклюзивного навчання, або підтримкою дітей 3 ООП (Професійний стандарт «Практичний психолог закладу освіти», 2020). Особливо помітним брак інклюзивної компетентності постає в порівнянні з прийнятим у тому ж році професійним стандартом «Вчитель початкових класів закладу загальної середньої освіти», де ця компетентність, по-перше, представлена i, по-друге, конкретизована в трьох позиціях: здатність створювати умови, що забезпечують функціонування інклюзивного освітнього середовища; здатність до педагогічної підтримки осіб з особливими освітніми потребами; здатність забезпечувати сприятливі умови для кожного учня, залежно від його індивідуальних потреб, можливостей, здібностей та інтересів (Професійний стандарт за професією «Вчитель початкових класів закладу загальної середньої освіти», 2020).

У наукових розвідках Т. Саврасової-В'юн зроблено систематизацію змісту професійнопсихологічної компетентності психолога за різними підходами (аксіологічним, компетентнісним, системним та діяльнісним) (Саврасова-В'юн, 2015: 241-254). За цими узагальненнями стає зрозуміло, що більшість авторів визначають поняття «професійнопсихологічна компетентність» як сукупність знань, вмінь, особистісних якостей, цінностей й досвіду, що дає змогу здійснювати професійну діяльність та досягати ефективного вирішення професійних завдань. Автор статті до структури професійно-психологічної компетентності віднесла компоненти: мотиваційно-ціннісний; емоційно-оцінний; діяльнісно-вольовий; 
професійно-особистісний; когнітивно-орієнтаційний. Означені показники, на думку автора, забезпечують ефективне якісне виконання зазначених вище функцій майбутньої педагогічної діяльності.

У моделі формування професійної компетентності майбутніх психологів Ю. В. Вінтюка обгрунтовано такі компоненти, як: цільово-мотиваційний, методологічноконцептуальний, стратегічно-нормативний, ммістово-організаційний, діяльніснопроцесуальний, діагностично-оціночний, результативно-коригуючий (Вінтюк, 2018: 42-48). Цінність запропонованої моделі полягає в тому, що автор вводить компонент «результативнокоригуючий» та пропонує систему критеріїв щодо сформованості професійної компетентності майбутніх психологів (теоретична компетенція; етично-ціннісна компетенція; комунікативна компетенція; інструментально-досвідна компетенція; персональна компетенція). Отже, ця модель передбачає наявність зворотного зв'язку між результатом та кожним блоком моделі, відповідно, компетентність психолога в цьому випадку базується на його відповідальній позиції й дає змогу визначати взаємозв'язок між його діями та їх наслідками. Вважаємо такий підхід актуальним з огляду на виклики суспільства, в тому числі як відповідальність щодо компетентності здійснювати діяльність психолога як учасника команди супроводу дітей 3 особливими освітніми потребами в закладах освіти. При цьому слід зазначити, що в цій моделі компетентностей майбутніх фахівців-психологів, як й у попередніх, практично відсутні компетентності, пов'язані зі спрямованістю на забезпечення відповідного, підтримувального та дієвого супроводу осіб з особливими потребами в інклюзивному освітньому просторі.

Мета дослідження - обгрунтувати необхідність визначення поняття «інклюзивна компетентність» практичного психолога як необхідної здатності в контексті професійної допомоги дітям з особливими освітніми потребами в закладі освіти.

Завдання дослідження: 1) на основі аналізу нормативно-правових документів, методичних матеріалів та наукових розвідок систематизувати проблематику щодо ефективної діяльності практичного психолога в інклюзивному освітньому середовищі; 2) виокремити важливі складники поняття «компетентність» та розробити модель інклюзивної компетентності практичного психолога в складі команди супроводу дітей 3 особливими освітніми потребами; 3) визначити формат ефективного підвищення фахової компетентності практичного психолога як учасника міждисциплінарної команди супроводу.

\section{Методи дослідження}

Методи аналізу законодавчої бази 3 інклюзивної освіти (передусім кадрового забезпечення та діяльності команди супроводу) та наукових досліджень проблеми; порівняльно-педагогічний аналіз для визначення відмінностей щодо інклюзивних процесів в Україні та інших країнах, а, також для диференціації змісту діяльності психолога в контексті інклюзивного навчання; системний аналіз, завдяки якому узагальнено чинники ефективної діяльності практичного психолога; метод моделювання для розробки структурних компонентів інклюзивної компетентності психологів та шляхів підвищення їхнього фахового рівня як учасників команди супроводу дітей з особливими потребами.

\section{Результати та дискусії}

Поняття «інклюзивна компетентність», так само як й «інклюзивна готовність» фахівця, $\epsilon$ відомим в науково-методичній літературі інших країн, й також - у наукових розвідках українських науковців. Так, білоруська дослідниця В. Хитрюк у своїх працях розглядає 
інклюзивну готовність педагога як системну характеристику особистості суб'єкта діяльності, що охоплює соціальне настановлення педагога на роботу в умовах інклюзивної освіти; попередню активність, схильність (налаштованість) й готовність діяти певним чином (Хитрюк, 2015). Ця модель інклюзивної готовності педагога, що була названа компетентнісною, реалізується з урахуванням потреб всіх суб'єктів інклюзивного освітнього простору. У контексті цієї моделі інклюзивну готовність педагога визначено як системну інтегральну якість суб'єкта професійної педагогічної діяльності, яка зумовлює професійний вибір, спрямованість (орієнтацію), поведінкові стратегії й методи професійно-педагогічної діяльності в актуальних умовах інклюзивної освіти.

У статті румунських науковців наголошено на тому, що інклюзивна компетентність виявляється у трансформації теоретичних знань в ефективні практики викладання (Blândul \& Bradea, 2017: 335-344). Автори статті доходять висновку про те, що у фахівців, які дотичні до інклюзивного навчання, необхідно розвивати психолого-педагогічні та методичні компетенції шляхом залучення їх до проєктів, або проходження курсів безперервного професійного навчання. Це передбачає реорганізацію функціональних структур школи, перегляд ставлення всіх працівників до нової форми організації школи, застосовування навчальних стратегій, орієнтованих на співпрацю дітей між собою, а також партнерську взаємодію їх з педагогами.

Українська дослідниця Н. Клименюк розкриває поняття інклюзивна компетентність (у контексті підготовки майбутніх соціальних працівників) відповідно до міжнародних орієнтирів (Клименюк, 2017: 72-86). За визначенням, представленим у статті, інклюзивна компетентність - це інтегративно-особистісна професійна сформованість, що зумовлює здатність здійснювати професійну діяльність у процесі інклюзивного супроводу, враховуючи різні можливості осіб з обмеженими можливостями здоров'я, забезпечуючи максимальну включеність їх у суспільне середовище через створення умов реалізації та розвитку особистісних можливостей особи (здібностей, знань, навичок, прагнень), прихованих можливостей, здатності до певної діяльності та соціальної адаптації. Перевага цього визначення полягає в тому, що воно здійснено з опорою на визнаний орієнтир у підходах до організації та впровадження допомоги і підтримки осіб з особливими освітніми потребами, а саме Міжнародна класифікація функціонування, обмежень життєдіяльності та здоров'я (МКФ), де особу з обмеженнями життєдіяльності й здоров'я розглядають у контексті іiі участі у життедіяльності.

Розглянемо зміст діяльності психолога за тими українськими нормативно-правовими документами, де йдеться про інклюзивне навчання. У відповідності до міжнародних стандартів в українському законодавстві затверджений формат здійснення супроводу дітей 3 ООП міждисциплінарною командою. Одним з учасників цієї команди є практичний психолог. У «Примірному положенні про команду психолого-педагогічного супроводу дитини з ООП в закладі загальної середньої та дошкільної освіти» розкрито такі основні функції, якими має володіти практичний психолог: вивчення та моніторинг психічного розвитку дитини з ООП; психологічний супровід дитини з ООП; надання корекційно-розвиткових послуг дитині з ООП згідно з індивідуальною програмою розвитку (ІПР) тощо (Примірне положення про команду психолого-педагогічного супроводу дитини з особливими освітніми потребами в закладі загальної середньої та дошкільної освіти, 2018). При цьому, ні в цьому Положенні, ні в інших документах нормативно-правової бази не представлено: необхідний діагностичний інструментарій для психологів щодо визначення сильних сторін дитини з ООП та її потреб; 
алгоритм розроблення психологом стратегії втручання у відповідності до визначених потреб та актуальних цілей розвитку дітей з ООП; особливостей реалізації стратегії, оцінювання та моніторингу динаміки розвитку цих дітей.

У Посадовій інструкції практичного психолога закладу загальної середньої освіти, що складена відповідно до вимог Положення про психологічну службу в системі освіти України (2018), подано такі напрями діяльності, як: діагностика, профілактика, корекція, навчальна діяльність, консультування, зв'язки з громадськістю, просвіта. Аналіз видів діяльності практичного психолога дає змогу визначити три суттєві недоліки, які, на наш розсуд, стосуються цієї Посадової інструкції: 1) інклюзивна складова практично відсутня; 2) брак положень, які б представляли можливості командної взаємодії психолога 3 іншими учасниками міждисциплінарного супроводу; 3) зміст корекційно-розвиткових програм сформульовано виключно як перелік негативних характеристик: «усунення труднощів» та «зниження ризиків», що характерно для медичної моделі інвалідності (Посадова інструкція практичного психолога закладу загальної середньої освіти, 2018).

У професійному стандарті «Практичний психолог закладу освіти» (2020р.) в розгорнутій таблиці «Опис трудових функцій» згадано про інклюзивне навчання в контексті певних «видів ситуацій», коли практичний психолог надає психологічну допомогу, серед яких: булінг, прояви насильства, шкідливі звички тощо (Професійний стандарт «Практичний психолог закладу освіти», 2020: 19). Зазначено також, що психолог повинен мати знання щодо психолого-педагогічних особливостей організації інклюзивного навчання та практичні навички щодо участі в різних видах діяльності, в тому числі складання індивідуальної програми розвитку та індивідуальної навчальної програми (Професійний стандарт «Практичний психолог закладу освіти», 2020: 24). Вважаємо такий підхід вкрай обмеженим щодо ролі психолога в інклюзивному процесі, тобто таким, що не передбачає його системну й послідовну роботу в напрямі підтримки дітей з ООП.

На жаль, у сучасних україномовних статтях також не знаходимо чіткого й послідовного представлення діяльності психолога в системі інклюзивного навчання. Замість конкретики частіше можна зустріти певні узагальнення стосовно його участі в інклюзивному процесі, наприклад, розмірковування про те, що в процесі підготовки до практичної діяльності психологу особливу увагу слід приділяти безпосередньому усвідомленню цінностей, які формуються на засадах людяності, толерантності, розуміння й духовності, особливо необхідних майбутнім практичним психологам для професійної діяльності в інклюзивному середовищі (Шолох, 2020: 177-184).

Невідповідним, на наш розсуд, є й уявлення про те, що психолог закладу освіти має здійснювати психологічний супровід навчання в інклюзивному середовищі, що охоплює: психологічну діагностику дітей й надання їм психопрофілактичної та психокорекційної допомоги (Марчак, 2020: 100). При цьому корекційна робота повинна узгоджуватися 3 навчально-виховною й передбачати використання програмового навчального матеріалу в процесі корекційних занять. Тут, так само як й у професійному стандарті, немає вбачання психолога як суб' єкта командної взаємодії, адже «психологічний супровід» психолога - це не «психолого-педагогічний супровід» команди супроводу. Окрім цього, помилковим, на нашу думку, є жорстке обмеження змісту занять психолога у відповідності до навчально-виховної роботи й програмовим навчальним матеріалом.

У цілому, можна констатувати, що певна увага до необхідності організовувати інклюзивні процеси наявна й у нормативно-правових матеріалах, й у наукових розвідках 
освітян. Але, передусім, наявний суттєвий розрив, так звана «дихотонічна напруга» (Martynchuk, Skrypnyk, Sofiy, Bahdanovich \& Hanssen, 2020: 148-167), за якої певні питання, згадані в українському законодавстві (універсальний дизайн та розумне пристосування; створення умов для соціалізації всіх дітей тощо), залишаються декларативними, а механізмів їх реалізації ще немає.

Дослідження, проведене групою українських дослідників (Мартинчук, Скрипник, 2020: 186-197), виявило суттєву невідповідність української нормативно-правової бази інклюзивної освіти європейським цінностям та керівним засадам. Так, йдеться про брак наріжних для інклюзивного процесу понять: (ціль інклюзивного навчання; SMART-ціль як серцевина індивідуальної програми розвитку тощо); нерозкритий зміст понять (інклюзивне освітнє середовище; якісна інклюзивна освіта, наступність, партнерство); поняття з викривленим щодо міжнародних норм змістом (послуги, команда супроводу, потенційні можливості дитини, потреби, моніторинг).

Наявний орієнтир в українській освіті на впровадження інклюзивного навчання, 3 одного боку, й практична відсутність визначення змісту й послідовності дій практичного психолога у контексті допомоги дітям 3 ООП, 3 іншого, актуалізують необхідність розроблення та долучення до системи компетентностей, якими має володіти цей фахівець, інклюзивної компетентності. Для опрацювання змісту інклюзивної компетентності ми спиралися на одну 3 моделей компетентностей, що охоплює мотиваційно-спонукальну, гностичну, діяльнісну, ціннісно-рефлексивну, комунікативну функції (Головань, 2008: 23-30). За цією моделлю системотвірною виокремлено діяльнісну функцію, що зумовлено змістом компетентності як уміння розв'язувати проблемні завдання в певній галузі, проєктувати якісну й результативну власну діяльність. Виконання такої діяльності є можливим за наявності у фахівця певної сукупності знань, на основі яких здійснюється усвідомлений вибір операцій для досягнення мети конкретної дії й правильного виконання цієї дії. Ці ідеї є дуже важливими в контексті підготовки (підвищення компетентності) практичних психологів щодо участі в інклюзивному процесі, адже тут наголошено на певній технологічності підготовки, що сприятиме набуттю фахівцями майстерності творчо й різнопланово діяти, розуміючи, які саме технології, методи й засоби вони можуть застосовувати задля досягнення якісного рівня інклюзивного навчання.

Нами розроблено конкретний зміст компетенцій як структурних компонентів інклюзивної компетентності, а саме:

особистісні - повага до різноманітності; спрямованість на участь у процесі інклюзивного супроводу з урахуванням різних можливостей дітей з ООП та прагнення досягати їхньої максимальної включеності в освітне середовище;

міжособистісні - здатність встановлювати психологічний контакт з усіма учасниками міждисциплінарного супроводу; здатність до командної взаємодії; здатність керувати процесом спілкування та організовувати педагогічно доцільну взаємодію в інклюзивному середовищі; уміння встановлювати доброзичливі міжособистісні відносини в інклюзивному освітньому просторі;

діяльнісні - здатність забезпечувати сприятливі умови для кожного учня, залежно від його індивідуальних потреб, можливостей, здібностей та інтересів; вміння оволодівати інклюзивними технологіями; вміння визначати сильні сторони дитини з ООП та їі потреби, розробляти індивідуальну програму розвитку; визначати зміст та алгоритм впровадження 
психологічних стратегій втручання, реалізовувати ці стратегії, здійснювати оцінювання та моніторинг динаміки розвитку дитини).

Орієнтир на інклюзивну компетентність при підготовці майбутніх психологів або у процесі підвищення кваліфікації вже досвідчених психологів, дасть змогу сформувати їхні професійні уміння у відповідності до вимог часу; сприятиме поліпшенню фахової підтримки дітей з особливими освітніми потребами в закладах освіти.

За проведеним нами попереднім дослідженням визначено, що однією з найкращих умов оволодіння новими технологіями $€$ безпосереднє навчання без відриву від професійної діяльності (або під час практики), що супроводжується неперервним експертним коучингом (Скрипник \& Бірюкова, 2020: 23-29). Наразі наявні різні формати, спрямовані на підвищення фахового рівня учасників міждисциплінарного супроводу, серед яких: курси підвищення кваліфікації, лекції, семінарські заняття, тренінги, майстер-класи. Водночас, кожна з цих форм проведення навчання відбувається, по-перше, з відривом від професійної діяльності, а, подруге, із задіянням одного або декількох представників тих чи інших закладів освіти, тих чи інших робітників інклюзивно-ресурсних центрів. Однак, зважаючи на те, що фахівці мають набувати компетентність щодо взаємодії у режимі командної взаємодії, передбачає необхідність здійснення навчання 3 охопленням усіх потенційних учасників команди супроводу, адже відомо, що налагодження дієвого командного супроводу принципово змінює продуктивність діяльності усіх учасників команд супроводу й уможливлює створення інклюзивного освітнього середовища, сприятливого для розвитку всіх учасників освітнього процесу.

Такому формату навчання відповідає визнаний на міжнародному рівні коучинг як підхід до професійного розвитку, в процесі якого експерт/коуч разом з учасниками створюють, відпрацьовують й удосконалюють потрібний зміст та алгоритм спільної діяльності. Важливими характеристиками коучингу є: безперервність і систематичність, співпраця, ефективне спілкування, спрямованість на спільне планування, моніторингові процеси й забезпечення зворотного зв’язку.

Переваги такого підходу полягають у можливості аналізувати всі актуальні різнобічні труднощі, які виникають в освітньому процесі, що уможливлює пошук шляхів вирішення складних ситуацій з повним урахуванням контексту ситуації та безпосередньо під час їх виникнення. Це дає змогу розробити необхідний план узгоджених дій щодо кожного учасника команди супроводу й реалізовувати послідовну діяльність, підтримуючи один одного. Участь у подібному форматі практичних психологів сприятиме набуттю ними компетентності щодо інклюзивних технологій й командної взаємодії, i, в цілому, позитивного досвіду впровадження інклюзивного навчання.

\section{Висновки}

Проведений аналіз змісту діяльності практичного психолога дав змогу дійти висновку про те, що в нормативно-правових розробках і професійній документації повністю відсутня інклюзивна компетентність практичного психолога, а в навчально-методичних розробках і наукових працях ця компетентність подається суперечливо й узагальнено.

Нами визначена така структура інклюзивної компетентності: особистісні (повага до різноманітності; спрямованість на участь у процесі інклюзивного супроводу задля досягнення дітьми з ООП максимальної включеності в освітній процес); міжособистісні (здатність до командної взаємодії; здатність керувати процесом спілкування та організовувати педагогічно 
доцільну взаємодію в інклюзивному середовищі тощо) та діяльнісні (вміння оволодівати інклюзивними технологіями, визначати сильні сторони дитини з ООП та іiі потреби, розробляти індивідуальну програму розвитку; визначати зміст та алгоритм впровадження психологічних стратегій втручання, реалізовувати ці стратегії, здійснювати оцінювання та моніторинг динаміки розвитку дитини тощо) компетенції. Вважаємо, що визначений зміст інклюзивної компетентності та формат підготовки й підвищення фахового рівня практичних психологів уможливить надання ними продуманої й цілеспрямованої допомоги дітям з ООП в інклюзивному освітньому просторі.

Перспективу подальших досліджень вбачаємо в експериментальній перевірці ефективності впровадження програми розвитку інклюзивної компетентності як однієї 3 найважливіших у діяльності практичного психолога в контексті організації цілеспрямованого й послідовного командного супроводу дітей з особливими освітніми потребами.

\section{Література}

1. Вінтюк, Ю.В. (2018). Модель формування професійної компетентності майбутніх психологів у ВНЗ. Вісник Черкаського університету. Серія «Педагогічні науки», 8, 42-48.

2. Головань, М.С. (2008). Компетенція і компетентність: досвід теорії, теорія досвіду. Вища освіта України, 3, 23-30.

3. Клименюк, Н. (2017). Формування інклюзивної компетентності в майбутніх соціальних працівників в умовах професійної підготовки. Педагогічні науки: теорія, історія, інноваційні технологї, 1(65), 72-86.

4. Мартинчук, О.В., \& Скрипник, Т.В. (2020). Потреба у концептуалізації понять інклюзивної освіти в Україні як виклик сьогодення. Актуальні питання корекційної освіти (педагогічні науки): збірник наукових пращьь, 16(1), 186-197.

5. Марчак, Т.А. (2020). Психолого-педагогічний супровід навчання дітей з порушенням психофізичного розвитку як складова інклюзивного навчання. Матеріали міжнародної наукової конференції «Проблеми та перспективи реалізаџіi та впровадження міждисииплінарних наукових досягнень» (Київ, 12 липня 2020), 97-101. Київ : МЦНД. https://doi.org/10.36074/12.06.2020.v1.06

6. Посадова інструкція практичного психолога закладу загальної середньої освіти (2018). Режим доступу: https://vseosvita.ua/library/posadova-instrukcia-prakticnogo-psihologa-zzsozrazok-354222.html

7. Примірне положення про команду психолого-педагогічного супроводу дитини 3 особливими освітніми потребами в закладі загальної середньої та дошкільної освіти (2018). Наказ МОН України № 609 від 08.06.2018. Режим доступу: https://zakon.rada.gov.ua/rada/show/v0609729-18\#Text

8. Професійний стандарт за професією «Вчитель початкових класів закладу загальної середньої освіти» (2020). Режим доступу: https://nus.org.ua/wp-content/uploads/2020/12/ Nakaz_2736.pdf

9. Професійний стандарт «Практичного психолога закладу освіти» (2020). Режим доступу: https://mon.gov.ua/storage/app/media/rizne/2020/12/Standart_Praktychnyy_psykholoh.pdf

10. Саврасова-В'юн, Т.О. (2015). Зміст і структура професійно-психологічної компетентності майбутніх педагогів. Освітологічний дискурс, 2(10), 241-254.

11. Скрипник, Т., \& Бірюкова, К. (2020). Неперервний експертний коучинг для підвищення компетентності учасників інклюзивного процесу в закладах освіти. Неперервна професійна освіта: теорія і практика, 1(62), 23-29. 
12. Хитрюк, В.В. (2015). Инклюзивная готовность педагога: генезис, феноменология, конщепџия формирования. (Монография). Барановичи : БарГУ.

13. Шолох, О.А. (2020). Ціннісні аспекти підготовки майбутніх психологів до діяльності в інклюзивному середовищі. Вісник Чернігівського національного педагогічного університету імені ТГ Шевченка. Серія: Педагогічні науки, 6(162), 177-184 .

14. Blândul, V.-C., \& Bradea, A. (2017). Developing psychopedagogical and methodical competences in special / inclusive education teachers. Problems of Education in the 21 st Century, 75(4), 335-344.

15. Global Education Monitoring Report Summary (2020): Inclusion and education: All means all. Paris : UNESCO.

16. Martynchuk, O., Skrypnyk, T., Sofiy, N.Z., \& Bahdanovich Hanssen, N. (2020). Inclusive education in Ukraine: Tension between policy and practice. Dialogues between Northern and Eastern Europe on the Development of Inclusion: Theoretical and Practical Perspectives. Great Britain : Routledge, 148-16.

17. Martynchuk, O., Skrypnyk, T., Maksymchuk, M, Babych, N., \& Biriukova, K. (2021). Professional readiness of future special education teachers for inclusive education in Ukraine. Society. Integration. Education. Proceedings of the International Scientific Conference, III, 159172.

\section{References}

1. Vintiuk, Yu.V. (2018). Model formuvannia profesiinoi kompetentnosti maibutnikh psykholohiv $\mathrm{u}$ VNZ [Model of formation of professional competence in future psychologists at higher educational establishments]. Visnyk Cherkaskoho universytetu. Seriia «Pedahohichni nauky»Visnik of the Cherkasy University. Series "Pedagogical Sciences", 8, 42-48 [in Ukrainian].

2. Holovan, M.S. (2008). Kompetentsiia i kompetentnist: dosvid teorii, teoriia dosvidu [Competence and competence: experience theory, experience theory]. Vyshcha osvita Ukrainy - Higher education in Ukraine, 3, 23-30 [in Ukrainian].

3. Klymeniuk, N. (2017). Formuvannia inkliuzyvnoi kompetentnosti v maibutnikh sotsialnykh pratsivnykiv v umovakh profesiinoi pidhotovky [The Formation of Inclusive Competence of the Future Social Workers During Professional Training]. Pedahohichni nauky: teoriia, istoriia, innovatsiini tekhnolohii - Pedagogical sciences: theory, history, innovation technologies, 1(65), 72-86 [in Ukrainian].

4. Martynchuk, O.V., \& Skrypnyk, T.V. (2020). Potreba u kontseptualizatsii poniat inkliuzyvnoi osvity v Ukraini yak vyklyk sohodennia [The need for conceptualizing the terms of inclusive education in Ukraine as a challenge of the present]. Aktualni pytannia korektsiinoi osvity (pedahohichni nauky): zbirnyk naukovykh prats - Actual problems of the correctional education, 16(1), 186-197 [in Ukrainian].

5. Marchak, T.A. (2020). Psykholoho-pedahohichnyi suprovid navchannia ditei z porushenniam psykhofizychnoho rozvytku yak skladova inkliuzyvnoho navchannia [Psychological and pedagogical support of teaching children with mental and physical disabilities as a component of inclusive education]. Materialy mizhnarodnoi naukovoi konferentsii «Problemy ta perspektyvy realizatsii ta vprovadzhennia mizhdystsyplinarnykh naukovykh dosiahnen» - Materials of the International Science Conference "Problems and Prospects of Realization and Implementation of Interdisciplinary Sciences" (Kyiv, July 12, 2020), 97-101. Kyiv : MTsND. https://doi.org/10.36074/12.06.2020.v1.06 [in Ukrainian].

6. Posadova instruktsiia praktychnoho psykholoha zakladu zahalnoi serednoi osvity [Job description of a practical psychologist of a general secondary education institution] (2018). 
Retrieved from https://vseosvita.ua/library/posadova-instrukcia-prakticnogo-psihologa-zzsozrazok-354222.html [in Ukrainian].

7. Prymirne polozhennia pro komandu psykholoho-pedahohichnoho suprovodu dytyny z osoblyvymy osvitnimy potrebamy $v$ zakladi zahalnoi serednoi ta doshkilnoi osvity [Indicative provision on the team of psychological and pedagogical support of a child with special educational needs in a general secondary and preschool education institution] (2018). Nakaz MON Ukrainy № 609 vid 08.06.2018. Retrieved from https://zakon.rada.gov.ua/rada/show/v0609729-18\#Text [in Ukrainian].

8. Profesiinyi standart za profesiieiu «Vchytel pochatkovykh klasiv zakladu zahalnoi serednoi osvity" [Professional standard for the profession "Primary school teacher of general secondary education"] (2020). Retrieved from https://nus.org.ua/wp-content/uploads/2020/12/Nakaz 2736.pdf [in Ukrainian].

9. Profesiinyi standart «Praktychnoho psykholoha zakladu osvity» [Professional standard "Practical psychologist of an educational institution"] (2020). Retrieved from https://mon.gov.ua/storage/app/media/rizne/2020/12/Standart_Praktychnyy_psykholoh.pdf [in Ukrainian].

10. Savrasova-V'un, T.O. (2015). Zmist i struktura profesiino-psykholohichnoi kompetentnosti maibutnikh pedahohiv [The content and structure of professional psychological competence of future teachers]. Osvitolohichnyi dyskurs - Osvitological discourse, 2(10), 241-254 [in Ukrainian].

11. Skrypnyk T., \& Biriukova, K. (2020). Neperervnyi ekspertnyi kouchynh dlia pidvyshchennia kompetentnosti uchasnykiv inkliuzyvnoho protsesu v zakladakh osvity [Continuous experts coaching to increase the competence of participants of the inclusive process in educational institutions]. Neperervna profesiina osvita: teoriia $i$ praktyka - Continuing professional education: theory and practice (series: pedagogical sciences), 1(62), 3-29 [in Ukrainian].

12. Khytriuk, V.V. (2015). Ynkliuzyvnaia hotovnost pedahoha: henezys, fenomenolohyia, kontseptsyia formyrovanyia [Inclusive readiness of the teacher: genesis, phenomenology, the concept of formation]. Baranovychy : BarHU [in Russian].

13. Sholokh, E. (2020). Tsinnisni aspekty pidhotovky maibutnikh psykholohiv do diialnosti $\mathrm{v}$ inkliuzyvnomu seredovyshchi [Valuable aspects of preparation of future psychologists for activities in an inclusive environment]. Visnyk Chernihivskoho natsionalnoho pedahohichnoho universytetu imeni TH Shevchenka. Pedahohichni nauky - Bulletin of the Chernigiv National Pedagogical University of the Name of TG Shevchenko (series: Pedagogical Sciences), 6(162), 177-184 [in Ukrainian].

14. Blândul, V.-C., \& Bradea, A. (2017). Developing psychopedagogical and methodical competences in special / inclusive education teachers. Problems of Education in the 21 st Century, 75(4), 335-344.

15. Global Education Monitoring Report Summary, 2020: Inclusion and education: All means all. Paris : UNESCO.

16. Martynchuk, O., Skrypnyk, T., Sofiy, N.Z, \& Bahdanovich Hanssen, N. (2020). Inclusive education in Ukraine: Tension between policy and practice. Dialogues between Northern and Eastern Europe on the Development of Inclusion: Theoretical and Practical Perspectives. Great Britain : Routledge, 148-67.

17. Martynchuk, O., Skrypnyk, T., Maksymchuk, M, Babych N., \& Biriukova, K. (2021). Professional readiness of future special education teachers for inclusive education in Ukraine. Society. Integration. Education. Proceedings of the International Scientific Conference, III, 159172. 


\title{
CONTENT OF INCLUSIVE COMPETENCE OF A PSYCHOLOGIST AS A PARTICIPANT OF THE IEP TEAM FOR CHILDREN WITH SPECIAL EDUCATIONAL NEEDS \\ Karina Biriukova \\ Postgraduate Student of the Department Psychology of Personality and Social Practices \\ Institute of Human Sciences, Borys Grinchenko Kyiv University \\ 13b, Marshal Timoshenka Str., Kyiv, Ukraine, 04212 \\ k.biriukova.asp@kubg.edu.ua, http://orcid.org/0000-0002-6158-5060
}

\begin{abstract}
The article deals with the importance of effectively organized inclusive education as an indicator of quality education. We present a scientific study that reveals a significant discrepancy between Ukrainian legal framework for inclusive education to European values and guidelines; we also formulate the factors that complicate the implementation of inclusive education in Ukraine. The article focuses on the staffing for inclusive education and above all the position of a psychologist in an inclusive educational environment. The legal and regulatory, methodical and research materials devoted to the definition of the content and forms of a psychologist's activity in an educational institution have been systematized. A comparative analysis of the content and forms of the activity of a psychologist and other members of the IEP team has been carried out in the Ukrainian regulatory legislation. The article emphasizes that the standard "Practical psychologist of an educational institution" lacks inclusive competence, and the concept of "inclusive education" is given in the list of such situational interventions as bullying, violence and bad habits. The research on the available sources of the conceptual field of the term "inclusive competence" revealed insufficient specificity and compliance of this concept with the needs of the time. We emphasize the article's main focus which substantiates the concept of a practical psychologist's "inclusive competence" as a necessary ability to provide professional assistance to children with special educational needs in the educational institution. The developed structure of inclusive competence comprises personal, interpersonal and activity competencies. We have specified the content of these competencies and indicated that the best format for their creation is direct training accompanied by expert coaching. The focus on inclusive competence in the training of future psychologists or in the process of advanced training of already experienced psychologists will allow to form their professional skills in accordance to the requirements of the time; will help improve the professional support for children with special educational needs in educational institutions.
\end{abstract}

Keywords: inclusive education, inclusive competence, special educational needs, professional standard. 